\title{
Article
}

\section{The effects of benzofury (5-APB) on the dopamine transporter and 5-HT2- dependent vasoconstriction in the rat}

Dawson, Patrick, Opacka-Juffry, Jolanta, Moffatt, James, Daniju, Jusuf, Dutta, Neelashki, Ramsay, John and Davidson, Colin

Available at http://clok.uclan.ac.uk/18222/

Dawson, Patrick, Opacka-Juffry, Jolanta, Moffatt, James, Daniju, Jusuf, Dutta, Neelashki, Ramsay, John and Davidson, Colin ORCID: 0000-0002-8180-7943 (2014) The effects of benzofury (5-APB) on the dopamine transporter and 5HT2-dependent vasoconstriction in the rat. Progress in Neuropsychopharmacology and Biological Psychiatry, 48 . pp. 57-63. ISSN 02785846

It is advisable to refer to the publisher's version if you intend to cite from the work. http://dx.doi.org/10.1016/j.pnpbp.2013.08.013

For more information about UCLan's research in this area go to

http://www.uclan.ac.uk/researchgroups/ and search for <name of research Group>.

For information about Research generally at UCLan please go to http://www.uclan.ac.uk/research/

All outputs in CLoK are protected by Intellectual Property Rights law, including Copyright law. Copyright, IPR and Moral Rights for the works on this site are retained by the individual authors and/or other copyright owners. Terms and conditions for use of this material are defined in the policies page. 


\section{Accepted Manuscript}

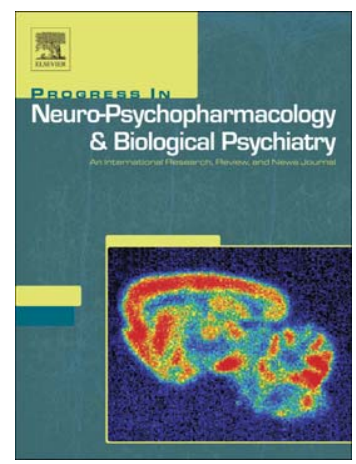

The effects of benzofury (5-APB) on the dopamine transporter and 5- $\mathrm{HT}_{2^{-}}$ dependent vasoconstriction in the rat

Patrick Dawson, Jolanta Opacka-Juffry, James D Moffatt, Yusuf Daniju, Neelakshi Dutta, John Ramsey, Colin Davidson

PII:

S0278-5846(13)00187-5

DOI:

doi: 10.1016/j.pnpbp.2013.08.013

Reference: PNP 8456

To appear in: $\quad$ Progress in Neuropsychopharmacology \& Biological Psychiatry

Received date: 2 August 2013

Revised date: $\quad 27$ August 2013

Accepted date: 28 August 2013

Please cite this article as: Dawson Patrick, Opacka-Juffry Jolanta, Moffatt James D, Daniju Yusuf, Dutta Neelakshi, Ramsey John, Davidson Colin, The effects of benzofury $(5-\mathrm{APB})$ on the dopamine transporter and $5-\mathrm{HT}_{2}$-dependent vasoconstriction in the rat, Progress in Neuropsychopharmacology \& Biological Psychiatry (2013), doi: 10.1016/j.pnpbp.2013.08.013

This is a PDF file of an unedited manuscript that has been accepted for publication. As a service to our customers we are providing this early version of the manuscript. The manuscript will undergo copyediting, typesetting, and review of the resulting proof before it is published in its final form. Please note that during the production process errors may be discovered which could affect the content, and all legal disclaimers that apply to the journal pertain. 


\section{The effects of benzofury (5-APB) on the dopamine transporter and 5-HT $\mathbf{2}^{-}$ dependent vasoconstriction in the rat.}

Patrick Dawson ${ }^{1 *}$, Jolanta Opacka-Juffry ${ }^{2 *}$ James D Moffatt $^{1}$, Yusuf Daniju ${ }^{2}$, Neelakshi Dutta ${ }^{2}$, John Ramsey ${ }^{3}$ and Colin Davidson ${ }^{1 \dagger}$

${ }^{1}$ Pharmacology and Cell Physiology, Division of Biomedical Science, St George's University of London, London SW17 0RE.

${ }^{2}$ Department of Life Sciences, University of Roehampton, London SW15 4JD.

${ }^{3}$ TICTAC Communications Ltd, St George's University of London, SW17 0RE.

*Joint first authors

${ }^{\dagger}$ Corresponding author cdavidso@sgul.ac.uk (0)208266 6135 


\begin{abstract}
5-APB, commonly marketed as 'benzofury' is a new psychoactive substance and erstwhile 'legal high' which has been implicated in 10 recent drug-related deaths in the UK. This drug was available on the internet and in 'head shops' and was one of the most commonly sold legal highs up until its recent UK temporary ban (UK Home Office). Despite its prominence, very little is known about its pharmacology. This study was undertaken to examine the pharmacology of 5-APB in vitro. We hypothesized that 5-APB would activate the dopamine and 5-HT systems which may underlie its putative stimulant and hallucinogenic effects. Autoradiographic studies showed that 5-APB displaced both $\left[{ }^{125} \mathrm{I}\right] \mathrm{RTI}-121$ and $\left[{ }^{3} \mathrm{H}\right]$ ketanserin from rat brain tissue suggesting affinity at the dopamine transporter and 5- $\mathrm{HT}_{2}$ receptor sites respectively. Voltammetric studies in rat accumbens brain slices revealed that 5-APB slowed dopamine reuptake, and at high concentrations caused reverse transport of dopamine. 5-APB also caused vasoconstriction of rat aorta, an effect antagonized by the 5- $\mathrm{HT}_{2 \mathrm{~A}}$ receptor antagonist ketanserin, and caused contraction of rat stomach fundus, which was reversed by the 5- $\mathrm{HT}_{2 \mathrm{~B}}$ receptor antagonist RS-127445. These data show that 5-APB interacts with the dopamine transporter and is an agonist at the 5- $\mathrm{HT}_{2 \mathrm{~A}}$ and 5- $\mathrm{HT}_{2 \mathrm{~B}}$ receptors in the rat. Thus 5APB's pharmacology is consistent with it having both stimulant and hallucinogenic properties. In addition, 5-APB's activity at the 5- $\mathrm{HT}_{2 \mathrm{~B}}$ receptor may cause cardiotoxicity.
\end{abstract}

\title{
Keywords:
}

Benzofury, accumbens, prefrontal cortex, dopamine transporter, 5- $\mathrm{HT}_{2}$, vasoconstriction

\section{Abbreviations:}

5-APB: 5-(2-aminopropyl)benzofuran; ACMD: Advisory Council on the Misuse of Drugs; aCSF: artificial cerebrospinal fluid; AUC: area under the curve; DA: dopamine; MDMA: 3,4, methylenedioxymethamphetamine; MDA: 3,4-methylenedioxyamphetamine; LSD: lysergic acid diethylamide; PFC: prefrontal cortex; ROI: region of interest. 


\section{Introduction}

Until recently, two benzofuran compounds - 5- and 6-APB (5- and 6-(2-

aminopropyl)benzofuran) - were being sold as the "legal high"/"designer drug" 'Benzofury'.

These drugs are structurally related to two other recreational drugs; Ecstasy (3,4,

methylenedioxymethamphetamine, MDMA) and 3,4-methylenedioxyamphetamine (MDA). 5and 6-APB are structural isomers and were first developed in the early 1990s (Monte et al., 1993). There has been difficulty in separating the 5- and 6-APB isomers, and perhaps the occurrence of the 4-APB isomer, but chemical analysis can now differentiate these isomers (Stanczuk et al., 2013). Anecdotal user reports suggest that benzofury has entactogenic and stimulant effects and that 5-APB is more potent than 6-APB. There is some suggestion that the drug may also have some psychedelic effects, but users do not appear to take 5-APB exclusively for this purpose. In the UK, Benzofury has been implicated in about 10 deaths since 2011. In all cases, 5- or 6-APB was found at postmortem, although because of polydrug use, it is often difficult to attribute death to a single drug (ICDP, personal communications). Anecdotal user reports suggest that this drug can cause hyperthermia, insomnia, increased heart rate and anxiety with some users reporting adverse effects similar to those produced by Ecstasy (ACMD report).

Psychostimulants are thought to mediate their rewarding effects through inhibition of the dopamine transporter or to cause direct dopamine release (Giros et al., 1996; Lee et al., 2001). Hallucinogenic drugs such as LSD, on the other hand, would be expected to have efficacy at 5$\mathrm{HT}_{2 \mathrm{~A}}$ receptors (Passie et. al, 2008). We thus first tested whether 5-APB could displace radioligands for the dopamine transporter and the $5-\mathrm{HT}_{2}$ receptors in rat brain tissue. Most drugs of abuse, but especially stimulants, increase dopamine efflux within the nucleus accumbens (Di Chiara and Imperato, 1988; Willuhn et al., 2010). We next examined the effect of 5-APB in a functional study, using electrically evoked dopamine efflux in the rat accumbens brain slice, measured by fast cyclic voltammetry. Finally, given the potential cardiovascular effects of agonists at 5- $\mathrm{HT}_{2}$ receptors (Dawson and Moffatt 2012) we examined the effects of 5-APB in displacing $\left[{ }^{3} \mathrm{H}\right]$ ketanserin from rat striatum and cortex and in functional assays for both 5-HT $\mathrm{H}_{2 \mathrm{~A}}$ agonist activity (rat aortic contraction; Villaźon et. al, 2002) and 5-HT $2 \mathrm{~B}$ agonist 
activity (rat gastric fundus contraction; Baxter et. al 1994).

\section{Methods}

\subsection{Animals}

Adolescent male Wistar rats aged 8 weeks ( $200 \mathrm{~g})$ were bred in-house and kept on a 12/12 h light/dark cycle, fed and watered ad libitum and housed 4 per cage. Animals were sacrificed by cervical dislocation without anaesthesia. All procedures were conducted in accordance with regulations under the UK Animals (Scientific Procedures) Act 1986. Male adolescent and not mature adult rats were used as human drug taking typically starts in adolescence; this is especially true for the novel psychoactive drugs which appear to be taken mostly by adolescent males, at least in the case of mephedrone (Vardakou et al., 2011; Carhart-Harris et al., 2011).

\subsection{Quantitative Autoradiography}

\subsubsection{Chemicals}

The radioligand for the dopamine transporter, $\left[{ }^{125} \mathrm{I}\right] \mathrm{RTI}-121$ (specific activity $81.4 \mathrm{TBq} / \mathrm{mM}$ ) and $\left[{ }^{3} \mathrm{H}\right]$ ketanserin for the $5-\mathrm{HT}_{2}$ receptor (specific activity $1.976 \mathrm{TBq} / \mathrm{mM}$ ) were purchased from Perkin Elmer. All chemicals apart from methysergide (Tocris Biosciences UK) were purchased from Sigma-Aldrich (Poole, UK). 5-APB was purchased from an internet supplier and chemically identified with GCMS and NMR.

\subsubsection{Rat brain tissue preparation.}

Rat brains were rapidly removed, frozen at $-40^{\circ} \mathrm{C}$ using dry ice and isopentane and stored at $80^{\circ} \mathrm{C}$. Frozen brains were coronally cut into $20 \mu \mathrm{m}$ sections in a rostro-caudal direction from +3.0 to $+1.0 \mathrm{~mm}$ versus bregma to harvest the prefrontal cortex, nucleus accumbens and caudate-putamen (Paxinos and Watson, 2005). Sections were collected onto polysine-coated 
slides and stored at $-80^{\circ} \mathrm{C}$ prior to autoradiography. Six rat brains were used per radioligand assay.

\subsubsection{In vitro quantitative autoradiography: Dopamine transporter binding}

The autoradiography procedure was based on Strazielle et al. (1998). Striatal sections were

preincubated in $0.05 \mathrm{M} \mathrm{NaPB} \mathrm{pH} 7.4$ and then incubated with $20 \mathrm{pM}\left[{ }^{125} \mathrm{I}\right] \mathrm{RTI} 121$ in NaPB pH 7.4 with increasing concentrations of 5-APB $(0-30 \mu \mathrm{M})$ for 60 minutes at room temperature. Non-specific binding was assessed in the presence of $200 \mu \mathrm{M}$ nomifensine. Air-dried slides were apposed to Kodak BioMax MR films for 3 days; autoradiograms were analysed using MCIDTM, Version 7.0, Imaging Research Inc., Interfocus Ltd, U.K. Flat-field correction was applied. Relative optical density was measured in the accumbens shell and dorso-lateral striatal regions of interest (ROIs); both left and right hemisphere ROIs were sampled from triplicate sections and their means were calculated to assess the specific binding.

\subsubsection{In vitro quantitative autoradiography: $5-H T_{2 A}$ receptor binding}

The procedure was based on Sato et al. (2010). Triplicate brain sections were preincubated in $0.05 \mathrm{M}$ Tris buffer $\mathrm{pH} 7.4$ and then incubated with $1 \mathrm{nM}\left[{ }^{3} \mathrm{H}\right]$ ketanserin in $0.05 \mathrm{M}$ Tris buffer $\mathrm{pH} 7.4$ with $1 \mu \mathrm{M}$ prazosin (to block binding to adrenergic receptors) and $100 \mathrm{nM}$ tetrabenazine (to block binding to the vesicular transporter) for 60 minutes at room temperature; increasing concentrations of 5-APB were added $(0-30 \mu \mathrm{M})$. Non-specific binding was assessed in the presence of $200 \mu \mathrm{M}$ methysergide. Air-dried slides were apposed to Kodak BioMax MR films for 8 weeks; autoradiograms were analysed using MCID ${ }^{\mathrm{TM}}$, Version 7.0, Imaging Research Inc., Interfocus Ltd, U.K., with flat field correction. Relative optical density was measured in the prefrontal cortex (PFC) and accumbens shell regions of interest (ROIs); both left and right ROIs were sampled from triplicate sections and their means were calculated to assess the specific binding. Sections of inferior quality were excluded from quantitative analysis hence $n=5$ in Figure 1D. 
The nucleus accumbens and PFC were chosen considering their involvement in brain responses to drugs of abuse (e.g. Koob and Volkov, 2010) and the high density of the 5-HT $2 \mathrm{~A}$ receptor in these brain areas (Sato et al., 2010).

\subsection{Fast cyclic voltammetry in accumbens brain slices}

\subsubsection{Drugs and salts}

Artificial cerebrospinal fluid (aCSF) was prepared as previously described (Brierley and Davidson, 2012): $\mathrm{NaCl} 126$ mM; KCl 4 mM; $\mathrm{KH}_{2} \mathrm{PO}_{4} 1.4$ mM; $\mathrm{MgSO}_{4} 1.3$ mM;

$\mathrm{NaHCO}_{3} 26 \mathrm{mM}$; D-glucose $4 \mathrm{mM} ; \mathrm{CaCl}_{2} 2.4 \mathrm{mM}$ in de-ionized water and oxygenated with $95 \% \mathrm{O}_{2} / 5 \% \mathrm{CO}_{2}$ at room temperature. These chemicals were purchased from Sigma-Aldrich (Poole, UK).

\subsubsection{Measurement of dopamine efflux with fast cyclic voltammetry}

Briefly, a triangular voltage waveform (Figure 2d) was applied to a carbon fibre microelectrode (7 $\mu \mathrm{m}$ x $50 \mu \mathrm{m}$ tip, as previously described; Brierley and Davidson, 2012) which oxidized monoamines at about $600 \mathrm{mV}$ versus a $\mathrm{Ag} / \mathrm{AgCl}$ reference electrode. The resulting current at the electrode surface was recorded. Calibration of this electrode in a known concentration of dopamine (Figure 2a and 2e) allowed the recorded Faradaic current to be converted to the concentration of dopamine. Voltammetric scans conducted at $8 \mathrm{~Hz}$ were performed by a Millar Voltammetric Analyser (PD Systems, West Molesey, UK), with the evoked current of the complete scan at the electrode and signals sampled at the oxidation peak (Figure 2d-f) captured using a CED1401 micro3 analogue-to-digital converter (Cambridge Electronic Design, UK) and Spike2 v7.1 data capture software.

\subsubsection{Accumbens brain slice preparation}

Following cervical dislocation brains were rapidly removed under ice-cold aCSF and $400 \mu \mathrm{m}$ sections were taken rostro-caudally from approximately +2.2 to $+1.0 \mathrm{~mm}$ versus bregma 
(Paxinos \& Watson, 1986) using a vibratome. A slice was transferred to a laminar flow recording chamber supplied with aCSF via gravity feed, at a flow rate of $2 \mathrm{ml} / \mathrm{min}$ and temperature in the recording chamber at $32.5 \pm 0.5^{\circ} \mathrm{C}$. Slices were left to equilibrate in this environment for $40 \mathrm{~min}$ prior to electrical stimulation. The recording microelectrode was placed in the accumbens shell at the start of the equilibration period to monitor background dopamine levels, as under certain circumstances (such as poor slice health or increased temperature) large spontaneous release of dopamine can occur (Davidson et al., 2011). We recorded in the accumbens shell because $5-\mathrm{HT}_{2 \mathrm{~A}}$ receptors are most prevalent in this part of the striatum (Mijnster et al., 1997; and see Figure 1) and the shell is thought to show the greatest acute effect of stimulants (Pontieri et la., 1996).

\subsubsection{Electrical stimulation protocol}

Dopamine efflux was evoked by a stimulation protocol designed to replicate the phasic burst firing pattern typical of midbrain dopamine neurons during presentation of salient reward related stimuli, such as drugs of abuse (Hyland et al., 2002). A train of 10 x $1 \mathrm{~ms} 10 \mathrm{~mA}$ pulses was applied at a frequency of $20 \mathrm{~Hz}$, with stimulus trains applied every $5 \mathrm{~min}$. Stimulus train parameters were programmed into the Spike 7 data capture program and applied to a bipolar steel electrode (A-M Systems, WA, USA), with tips approximately $300 \mu \mathrm{m}$ apart, and $200 \mu \mathrm{m}$ from the recording electrode.

\subsubsection{Data acquisition and analysis}

Changes in Faradaic current sampled at the dopamine oxidation peak were plotted by the Spike2 software. For each efflux event the area under the curve (AUC) was calculated (Yorgason et al., 2011). Stimulated efflux events were initiated every 5 min and following 3 stable consecutive baseline events 5-APB was added (Fig 2b). All data was expressed as a percentage of the mean pre-drug AUC.

\subsection{5-HT 2 receptor assays in peripheral tissue}


Male Wistar rats (200-300 g) were killed by cervical dislocation and the thoracic aorta and stomach were rapidly removed and placed in a modified Krebs' solution (composition (mM): $125 \mathrm{NaCl}, 4.6 \mathrm{KCl}, 2.5 \mathrm{CaCl}_{2}, 15.4 \mathrm{NaHCO}_{3}, 1 \mathrm{Na}_{2} \mathrm{HPO}_{4}, 0.6 \mathrm{MgSO}_{4}, 10 \mathrm{D}$-glucose). The aorta was freed from surrounding fat and other tissues and cut into $5 \mathrm{~mm}$ length rings. Strips of the longitudinal muscle $(5 \times 20 \mathrm{~mm})$ of the gastric fundus (without mucosa) were prepared as described by Baxter et al. (1994). Both tissues were mounted in conventional organ baths bubbled with $95 \% \mathrm{O}_{2} / 5 \% \mathrm{CO}_{2}$ and maintained at $37^{\circ} \mathrm{C}$. Isometric recordings were made using force transducers connected to Powerlab AD converter (AD Instruments) and recorded using Chart for Windows (version 5, AD Instruments).

\subsubsection{Vasoconstriction in the rat aorta}

Rings of aorta were mounted on two longitudinal hooks, one acting as an anchor in the organ bath and the other connected to a force transducer. The preparations were initially stretched to a passive tension of $20 \mathrm{mN}$ and then allowed to equilibrate for 30 minutes. Subsequently, a reference contraction was produced by adding $60 \mathrm{mM} \mathrm{KCl}$ for 5 minutes before several washes and a further 30 minute equilibration period. Antagonists were added at the beginning of this equilibration period. Subsequently, cumulative additions of 5-APB were added to the bath in half-log increments. Experiments were performed using pairs of rings from the same animal, with one ring acting as a control.

\subsubsection{Muscle contractions/relaxations in the rat fundus}

Strips of gastric fundus were connected to an anchor in the organ bath and the transducer using 5-0 surgical silk. The experimental protocol for these experiments was identical to that above for rat aorta, except that the reference contraction was elicited by $100 \mu \mathrm{M}$ methacholine.

\subsection{Statistical Analysis}

Autoradiography data on $\left[{ }^{125} \mathrm{I}\right] \mathrm{RTI}-121$ and $\left[{ }^{3} \mathrm{H}\right]$ ketanserin radioligand binding were analyzed using a 2-way ANOVA with Tukey's post-hoc tests. Voltammetric data were analyzed using 
1-way ANOVA (SigmaStat) with Tukey’s post-hoc tests.

Cumulative concentration-effect data from aorta and fundus were fitted to sigmoid curves using Graphpad Prism to determine $\mathrm{pEC}_{50}$ values for agonists. All other statistical tests were also performed using Graphpad Prism. The effects of the 5- $\mathrm{HT}_{2 \mathrm{~A}}$ and $5-\mathrm{HT}_{2 \mathrm{~B}}$ antagonists, respectively, were compared with controls by comparing the maximal responses, as $\mathrm{pEC}_{50}$ values could not be estimated reliably in antagonist-treated preparations. Comparisons were made using unpaired t-tests (with Welch's correction for unequal standard deviations, as appropriate).

Data are presented as mean \pm standard error of mean (SEM), with significance set at $\mathrm{p}<0.05$.

\section{Results}

\subsection{Autoradiography}

3.1.1. Competition between 5-APB and $\left[{ }^{125} \mathrm{I}\right] \mathrm{RTI} 121$ at the dopamine transporter.

The displacement of $\left[{ }^{125}\right.$ I]RTI121 by 5-APB was examined in both caudate and accumbens and Figure 1A shows autoradiograms of relevant brain sections labeled with this radioligand. There was a marked concentration-dependent effect of 5-APB on the intensity of iodine-125 signal in brain tissue, indicating competition between 5-APB and [ ${ }^{125}$ I]RTI121. Two-way ANOVA revealed no significant effect of brain area $(\mathrm{p}>0.05)$, but there was a significant effect of 5APB concentration in both caudate $(F=22.557 ; \mathrm{p}<0.001)$ and accumbens $(\mathrm{F}=31.709 ; \mathrm{p}<$ $0.001)$ but no brain area X concentration interaction $(\mathrm{P}>0.05)$. Tukey's test showed that both 10 and $30 \mu \mathrm{M} 5$-APB caused significantly greater displacement of $\left[{ }^{125} \mathrm{I}\right] \mathrm{RTI}-121$ than any other concentrations while $3 \mu \mathrm{M}$ 5-APB caused a significant displacement of [ $\left.{ }^{125} \mathrm{I}\right] \mathrm{RTI}-121$ versus controls where no 5-APB was present (Total binding; Fig 1C).

3.1.2. Competition between 5-APB and $\left[{ }^{3} \mathrm{H}\right]$ ketanserin at the $5-\mathrm{HT}_{2 \mathrm{~A}}$ receptor. 
The displacement of $\left[{ }^{3} \mathrm{H}\right]$ ketanserin by 5 -APB was examined in both accumbens and prefrontal cortex (PFC). Figure 1B shows representative autoradiograms of brain sections labeled with $\left[{ }^{3} \mathrm{H}\right]$ ketanserin - there was an observable reduction in the tritium signal in the cortical and accumbens areas, which was dependent on the concentration of 5-APB. This was consistent with the competition between 5-APB and the radioligand. Two-way ANOVA revealed no significant effect of brain area $(\mathrm{p}>0.05)$, but there was a significant effect of 5-APB concentration in both PFC $(F=24.441 ; p<0.001)$ and accumbens $(F=28.121 ; p<0.001)$, but no brain area $\mathrm{X}$ concentration interaction $(\mathrm{P}>0.05)$. Tukey's test showed that both $10 \mu \mathrm{M}$ and $30 \mu \mathrm{M} 5$-APB caused significantly greater displacement of $\left[{ }^{3} \mathrm{H}\right]$ ketanserin than any other concentrations while $3 \mu \mathrm{M}$ 5-APB caused a significant displacement of [ $\left.{ }^{3} \mathrm{H}\right]$ ketanserin versus controls with no 5-APB (Total binding; Fig 1D).

\subsection{Dopamine efflux in accumbens brain slices}

5-APB has a chemical structure quite similar to 5-HT, therefore, we first tested whether 5-APB itself was electroactive, as if it was then it could interfere with our voltammetric dopamine measurements. Figures $2 \mathrm{c}$ and $2 \mathrm{~g}$ show that 5 -APB was not electroactive; there were no oxidation and reduction peaks associated with 5-APB, at least up to $10 \mu \mathrm{M}$.

On electrical stimulation (10 pulses at $20 \mathrm{~Hz}$ ) the mean peak dopamine levels was $218 \pm 19$ $\mathrm{nM}$ with a reuptake time-constant of $1.25 \pm 0.17 \mathrm{~s}$. One-way ANOVA revealed that 5-APB showed a concentration dependent increase in evoked dopamine (Figure 3; F = 10.78, p < 0.001 ), as determined by the AUC after electrical stimulation. Tukey's test showed that $10 \mu \mathrm{M}$ 5-APB had a greater effect than all other concentrations ( $\mathrm{p}<0.01)$. On 2 out of 3 occasions 10 $\mu \mathrm{M} 5$-APB caused a small increase $($ mean $=428 \mathrm{nM})$ in basal (non-stimulated) levels of dopamine (Figures $2 \mathrm{~b}$ and $2 \mathrm{f}$ ).

\subsection{Effect of 5-APB in the periphery}

\subsubsection{Vasoconstriction at rat aorta}


5-APB produced erratic contractile responses with maxima ranging from $7-127 \%(\mathrm{n}=5)$ of the $\mathrm{KCl}$ reference contraction, making an analysis of the effect of the 5- $\mathrm{HT}_{2 \mathrm{~A}}$ antagonist ketanserin $(0.1 \mu \mathrm{M})$ difficult, although the drug clearly blocked responses in all preparations (not shown). The addition of nifedipine to block voltage-gated calcium channels rendered responses to 5APB much more consistent between tissues, albeit at the compromise of a loss of amplitude. Under these conditions, 5-APB had a $\mathrm{pEC}_{50}$ of $5.11 \pm 0.08$, with a mean response amplitude of $15.7 \pm 1.4 \%(n=4)$; responses were abolished in preparations treated with ketanserin $(0.1 \mu \mathrm{M}$; figure $4 \mathrm{~A}$ ). Under the same conditions, 5 -HT produced responses with $\mathrm{pEC}_{50}$ of $5.38 \pm 0.09$ and a maximum of $158.5 \pm 9.3 \%$ which were also abolished by ketanserin $(0.1 \mu \mathrm{M}$; not shown).

\subsubsection{Contractions in rat fundus}

5-HT $\left.\left(\mathrm{pEC}_{50} 7.643 \pm 0.19 ; \mathrm{n}=5\right), \mathrm{MDMA}_{\left(\mathrm{pEC}_{50}\right.} 6.833 \pm 0.17 ; \mathrm{n}=6\right)$ and 5-APB $\left(\mathrm{pEC}_{50} 7.35 \pm\right.$ 0.34 ) all caused contractions of rat gastric fundus preparations (figure 4B). We examined MDMA as an internal control, as it is known to act on 5- $\mathrm{HT}_{2 \mathrm{~B}}$ receptors. In comparison to 5HT, 5-APB and MDMA appeared to be partial agonists as the maximal responses to these drugs were lower than 5-HT itself. The concentration-effect curves for all three agonists were significantly right-shifted by the 5- $\mathrm{HT}_{2 \mathrm{~B}}$ antagonist RS 127445 (1 $\mu \mathrm{M}$; Bonhaus et al., 1999); the results for 5-APB are shown in figure $4 \mathrm{C}$. 


\section{Discussion.}

We have shown that 5-APB binds to the dopamine transporter, blocks reuptake of dopamine and, at high concentrations, causes an increase in basal dopamine. This increase in basal dopamine is probably through reverse transport where amphetamine-like compounds can displace dopamine from synaptic vesicles (Sulzer et al., 2005). We have also shown that 5APB binds to the 5- $\mathrm{HT}_{2 \mathrm{~A}}$ receptor in prefrontal cortex and nucleus accumbens and in rat vascular studies we have shown that $5-\mathrm{APB}$ is an agonist at both the $5-\mathrm{HT}_{2 \mathrm{~A}}$ and $5-\mathrm{HT}_{2 \mathrm{~B}}$ receptors. The present findings suggest potential addictive, hallucinogenic and vasoconstrictive properties of 5-APB, which should be of concern to policy makers. Only one previous study has examined the pharmacology of 5-APB (Iversen et al., 2013). In radioligand binding studies of 49 human molecular targets, Iversen et al., (2013) found 5-APB to have high affinity $\left(\mathrm{pK}_{\mathrm{i}}>\right.$ 6) only at the 5- $\mathrm{HT}_{2 \mathrm{~B}}\left(\mathrm{pK}_{\mathrm{i}}=7.85\right), 5-\mathrm{HT}_{2 \mathrm{C}}\left(\mathrm{pK}_{\mathrm{i}}=6.28\right), \alpha_{2 \mathrm{~B}}\left(\mathrm{pK}_{\mathrm{i}}=6.16\right), \alpha_{2 \mathrm{C}}\left(\mathrm{pK}_{\mathrm{i}}=6.31\right)$, DAT $\left(\mathrm{pK}_{\mathrm{i}}=7.07\right)$ and SERT $\left(\mathrm{pK}_{\mathrm{i}}=6.26\right)$. In addition, functional studies in HEK-T cells expressing the human 5- $\mathrm{HT}_{2 \mathrm{~B}}$ receptor showed that 5-APB had a $\mathrm{pEC}_{50}$ of 7.82 at the $5-\mathrm{HT}_{2 \mathrm{~B}}$ site.

Our autoradiographic results suggest that 5-APB competes with $\left[{ }^{125} \mathrm{I}\right] \mathrm{RTI}-121$ at the dopamine transporter in a concentration-dependent manner. There is also a concentration-dependent competition between 5 -APB and $\left[{ }^{3} \mathrm{H}\right]$ ketanserin at $5-\mathrm{HT}_{2 \mathrm{~A}}$ receptors, the site of action of hallucinogens (Nichols, 2004; Egan et al., 1998; Passie et al., 2008). To our knowledge, this is the first demonstration of 5-APB binding to the dopamine transporter and 5- $\mathrm{HT}_{2 \mathrm{~A}}$ receptor in rat brain tissue. The present DAT effect is consistent with the recent findings by Iversen et al. (2013) derived from in vitro studies on cell lines

The voltammetry studies suggest that 5-APB is not electroactive and does not affect electrode sensitivity (Davidson et al., 2000). These functional neurochemistry studies show 5-APB to be a modest stimulant with a profile more like amphetamine than cocaine. The effect of 5-APB on the AUC of electrically evoked accumbens dopamine is not quite as great as that of stimulants such as cocaine, which increase the AUC by 3-and 6-fold at 1 and $10 \mu \mathrm{M}$ respectively in the accumbens core (Yorgason et al., 2011). In the accumbens shell, we saw only a significant 
increase at $10 \mu \mathrm{M}$ (5-fold versus baseline) and although $1 \mu \mathrm{M}$ 5-APB nearly doubled the AUC, this was not statistically significant. On the other hand, 5-APB was able to increase basal levels of dopamine (Figures $2 \mathrm{~b}$ and $2 \mathrm{f}$ ), an effect most often associated with amphetamine-like compounds and usually attributed to reverse transport (Sulzer et al., 2005). Typically it is found that stimulants have a greater effect on dopamine efflux in the accumbens shell versus the core (Pontieri et al., 1996), thus our results are relatively modest. Taken together, the increased AUC of electrically evoked dopamine and the increase in basal dopamine, we suggest that 5-APB is a modest amphetamine-like stimulant. Although not tested in the present study, amphetamine-like drugs have been shown to cause hyperthermia (Levi et al., 2012) and neurotoxicity (Davidson et al., 2001). Hyperthermic effects of 5-APB/benzofury have been reported by Emergency departments (ACMD report) and by online user groups (Drugs Forum website).

While effects on brain transporters and receptors are critical to the rewarding and addictive properties of drugs of abuse, it is the effects found in the periphery that are more likely to contribute directly to drug-related deaths. Abused drugs, such as the psychostimulants cocaine and the amphetamines, are clearly associated with increased risks of cardiovascular complications such as myocardial infarction and stroke due to their effects on sympathetic neurotransmitter uptake and release (Petitti et al., 1998). The drugs which are potentially the most dangerous are likely to be those that cause a fast and large increase in accumbens dopamine levels, carrying higher risks of addiction (Fowler et al., 2001), combined with peripheral cardiovascular effects which are likely to be toxic after chronic use (Dawson and Moffatt, 2012).

Activation of the 5-HT system throughout the body has vasopressor effects and 5-HT receptors have been considered as potential targets for novel hypertensive drugs. Indeed, the 5- $\mathrm{HT}_{2 \mathrm{~A}}$ receptor antagonist which we have used in this study, ketanserin, was a potent antihypertensive drug, but was withdrawn due to associations with torsade de pointes (Nagatomo et al., 2004). The hallucinogen LSD appears to act as a partial agonist of both 5- $\mathrm{HT}_{2 \mathrm{~A}}$ and 5- $\mathrm{HT}_{1 \mathrm{~A}}$ receptors (Halberstadt and Geyer, 2011; Passie et al., 2008), with effects via 5- $\mathrm{HT}_{2 \mathrm{~A}}$ receptors predominating. The two main receptors expressed by vascular smooth muscle are $5-\mathrm{HT}_{2 \mathrm{~A}}$ and 
5-HT ${ }_{1 \mathrm{~B}}$ (Kaumann and Levy, 2006) and their expression varies between vascular beds. For example, $5-\mathrm{HT}_{1 \mathrm{~B}}$ receptors predominate in cerebral arteries while in most other arteries $5-\mathrm{HT}_{2 \mathrm{~A}}$ receptors are most highly expressed. The displacement of ketanserin in our ligand binding studies would suggest that 5-APB might be vasoactive. We thus examined the effects of 5APB in the rat aorta and found it to cause vasoconstriction, an effect completely inhibited by ketanserin.

In our initial experiments 5-APB produced contractions of rat aorta that differed markedly in efficacy from preparation to preparation, a phenomenon not observed in the case of 5-HT itself. We found that after blockade of voltage-gated calcium channels with nifedipine, the erratic behaviour of the preparations was reduced and more consistent results were obtained. Interestingly, nifedipine had much less of an effect on the more reproducible responses to 5HT (not shown) than it did on those in response to 5-APB, an observation we have made previously with hallucinogenic 5- $\mathrm{HT}_{2 \mathrm{~A}}$ agonists in this assay (Dawson \& Moffatt, 2012, which may relate to agonist-dependent signalling or functional selectivity (Abbas \& Roth, 2008). Although the erratic responses to 5-APB in the absence of nifedipine make it difficult to comment on the efficacy of this drug, we note that the largest response produced (127\%) is still less than the mean maximum for 5-HT (158\%), suggesting that this compound is a partial agonist of 5-HT $2 \mathrm{~A}$ receptors, in common with most hallucinogenic $5-\mathrm{HT}_{2 \mathrm{~A}}$ agonists (Glennon, 1990). It is uncertain if the extreme variability in vascular responsiveness to 5-APB that we have shown here and found with other hallucinogenic 5- $\mathrm{HT}_{2 \mathrm{~A}}$ agonists (manuscript in preparation) has any significance in man, but may relate to individual adverse effects of the drug.

The development of heart valve fibrosis is thought to be mediated via activation of 5- $\mathrm{HT}_{2 \mathrm{~B}}$ receptors. Drugs such as the anorexic fenfluramine and the anti-Parkinson drug pergolide, which both activate the 5- $\mathrm{HT}_{2 \mathrm{~B}}$ receptor, have been withdrawn because of their implication in valvulopathy after long-term use (Bhattacharyya et al., 2009; Hutcheson et al., 2011; Rothman and Baumann, 2002; Rothman et al., 2000). The chronic use of legal highs with similar action at $5-\mathrm{HT}_{2 \mathrm{~B}}$ receptors may produce a similar toxic effect. Ecstasy (MDMA) is an abused drug with such a risk profile (Setola et al., 2003). Indeed, MDMA directly induces heart valve 
fibroblast proliferation in vitro via 5- $\mathrm{HT}_{2 \mathrm{~B}}$ receptors (Setola et al., 2003). Valvulopathies are found in regular MDMA users, many of whom take MDMA only on weekends but over a period of several months or years (Bhattacharyya et al., 2009). A simple and sensitive in vitro assay for acute effects at the $5-\mathrm{HT}_{2 \mathrm{~B}}$ receptor is the rat gastric fundus contraction assay, first described by (Sir) John Vane. Here we found 5-APB to cause contraction of the rat fundus, an effect antagonised by the specific 5- $\mathrm{HT}_{2 \mathrm{~B}}$ receptor antagonist RS127445 (Bonhaus et al., 1999). We also found 5-HT and MDMA to cause contraction of the fundus, with 5-APB having a greater efficacy than MDMA, a drug already linked to valvulopathies (Bhattacharyya et al., 2009). As in the 5- $\mathrm{HT}_{2 \mathrm{~A}}$ assay (above), 5-APB appeared to be a partial agonist at the 5$\mathrm{HT}_{2 \mathrm{~B}}$ receptor, as is the case for MDMA (present study; Setola et al., 2003) and - even more so - the MDMA metabolite 3,4-methylenedioxyamphetamine (MDA; Setola et al., 2003). The submicromolar potency of 5-APB at 5- $\mathrm{HT}_{2 \mathrm{~B}}$ receptors is of some concern. Indeed, of all the assays examined in this study 5-APB had the greatest potency in this system. Activation of 5$\mathrm{HT}_{2 \mathrm{~B}}$ receptors is inevitable if users imbibe enough 5-APB to interfere with monoamine reuptake and release - the principle effect sought by users.

There are a number of limitations to this study that should be considered. First the work was all done in adolescent male rats and extrapolation of these results to other age groups or females should be done with caution. Second, we only examined acute effects of 5-APB and these were examined in vitro. It would be of interest to examine the long-term effects of 5-APB on behaviour and the neuro- and cardiovascular systems. In particular, to determine if this drugs is addictive, and also to test its proposed cardiotoxicity and possibly, given its amphetamine-like profile, whether it causes hyperthermia and even neurotoxicity.

In conclusion, we have shown that 5-APB is a stimulant with multiple effects on the dopaminergic system. This drug also has affinity for 5- $\mathrm{HT}_{2 \mathrm{~A}}$ and 5- $\mathrm{HT}_{2 \mathrm{~B}}$ receptors, which have the potential for cardiovascular harm, including valvulopathy. This combination of addiction potential and cardiovascular toxicity almost certainly represents a public health problem. 


\section{References}

Abbas, A., Roth, B.L., 2008. Arresting serotonin. Proc. Natl. Acad. Sci. 105, 831-832.

ACMD report on Benzofury.

https://www.gov.uk/government/uploads/system/uploads/attachment_data/file/204808/J_TCD

O_report_on_5-6APB_and_NBOMe_compounds.pdf (accessed July 10th 2013).

Baxter, G.S., Murphy, O.E., Blackburn, T.P., 1994. Further characterization of 5hydroxytryytamine receptors (putative 5-HT2B) in rat stomach fundus longitudinal muscle. $\mathrm{Br}$ J Pharmacol 112, 323-331.

Bhattacharyya, S., Schapira, A.H., Mikhailidis, D.P., Davar, J., 2009. Drug-induced fibrotic valvular heart disease. Lancet 374, 577-585.

Bonhaus, D.W., Flippin, L.A., Greenhouse, R.J., Jaime, S., Rocha, C., Dawson, M., Van Natta, K., Chang, L.K., Pulido-Rios, T., Webber, A., Leung, E., Eglen, R.M., Martin, G.R., 1999. RS127445: a selective, high affinity, orally bioavailable 5- $\mathrm{HT}_{2 \mathrm{~B}}$ receptor antagonist. Br. J.

Pharmacol. 127, 1075-1082.

Brierley, D.I., Davidson, C. 2013. Harmine augments electrically evoked dopamine efflux in the nucleus accumbens shell. J. Psychopharmacol. 27, 98-108.

Carhart-Harris, R.L., King, L.A., Nutt, D.J. 2011. A web-based survey on mephedrone. Drug Alcohol Depend. 118, 19-22.

Davidson, C., Ellinwood, E.H., Douglas, S.B., Lee, T.H. 2000. Effect of cocaine, nomifensine, GBR 12909 and WIN 35428 on carbon fiber microelectrode sensitivity for voltammetric recording of dopamine. J. Neurosci. Meth. 101, 75-83. 
Davidson, C., Gow, A.J., Lee, T.H., Ellinwood, E.H. 2001. Methamphetamine neurotoxicity: necrotic and apoptotic mechanisms and relevance to human abuse and treatment. Brain Res. Rev. 36, 1-22.

Davidson, C., Chauhan. N,K., Knight, S., Gibson, C.L., Young, A.M.J. 2011. Modelling ischaemia in vitro: effects of temperature and glucose concentration on dopamine release evoked by oxygen and glucose depletion in a mouse brain slice. J. Neurosci. Meth. 202, 165172.

Dawson, P., Moffatt, J.D. 2012. Cardiovascular toxicity of novel psychoactive drugs: lessons from the past. Prog. Neuropsychopharmacol. Biol. Psychiatry. 39, 244-52.

Di Chiara, G., Imperato, A. 1988. Drugs abused by humans preferentially increase synaptic dopamine concentrations in the mesolimbic system of freely moving rats. Proc. Nat. Acad. Sci. $85,6274-5278$.

Drugs Forum http://www.drugs-forum.com/forum/showthread.php?t=154505, accessed July $9^{\text {th }} 2013$.

Egan, C.T., Herrick-Davis, K., Miller, K., Glennon, R.A., Teitler, M. 1998. Agonist activity of LSD and lisuride at cloned 5HT2A and 5HT2C receptors. Psychopharmacol. 136, 409-414.

Fowler, J.S., Volkow, N.D., Wang, G.J., Gatley, S.J., Logan, J. 2001. [11]Cocaine: PET studies of cocaine pharmacokinetics, dopamine transporter availability and dopamine transporter occupancy. Nuclear Med. Biol. 28, 561-572.

Giros, B., Jaber, M., Jones, S.R., Wightman, R.M., Caron, M.G. 1996. Hyperlocomotion and indifference to cocaine and amphetamine in mice lacking the dopamine transporter. Nature $379,606-612$.

Glennon, R.A. 1990. Do classical hallucinogens act as 5-HT2 agonists or antagonists? Neuropsychopharmacol. 3, 509-517. 
Halberstadt, A.L., Geyer, M.A. 2011. Multiple receptors contribute to the behavioral effects of indoleamine hallucinogens. Neuropharmacol. 61, 364-381.

Hutcheson, J.D., Setola, V., Roth, B.L., Merryman, W.D. 2011. Serotonin receptors and heart valve disease - it was meant 2B. Pharmacol. Ther. 132, 146-157.

Hyland, B.I, Reynolds, J.N., Hay, J., Perk, C.G., Miller, R. 2002. Firing modes of midbrain dopamine cells in the freely moving rat. Neurosci. 114, 475-492.

ICDP; International Centre for Drug Policy http://www.sgul.ac.uk/research/projects/icdp.

Iversen, L., Gibbons, S., Treble, R., Setola, V., Huang, X.P., Roth, B.L. 2013. Neurochemical profiles of some novel psychoactive substances. Eur. J. Pharmacol. 700, 147-151.

Kaumann, A.J., Levy, F.A. 2006. 5-Hydroxytryptamine receptors in the human cardiovascular system. Pharmacol. Ther. 111, 674-706.

Koob, G.F., Volkov, N.D. 2010. Neurocircuitry of Addiction. Neuropsychopharmacol. 35, 217-238.

Lee, T.H., Balu, R., Davidson, C., Ellinwood, E.H. 2001. Differential time-course profiles of dopamine release and nuptake changes induced by three dopamine uptake inhibitors. Synapse 41, 301-310.

Levi, M.S., Divine, B., Hanig, J.P., Doerge, D.R., Vanlandingham, M.M., George, N.I., Twaddle, N.C., Bowyer, J.F. 2012. A comparison of methylphenidate-, amphetamine-, and methamphetamine-induced hyperthermia and neurotoxicity in male Sprague-Dawley rats during the waking (lights off) cycle. Neurotoxicol. Teratol. 34, 253-262.

Mijnster, M.J., Raimundo, A.G., Koskuba, K., Klop, H., Docter, G.J., Groenewegen, H.J., Voorn, P. 1997. Regional and cellular distribution of serotonin 5-hydroxytryptamine2a 
receptor mRNA in the nucleus accumbens, olfactory tubercle, and caudate putamen of the rat. J. Comp. Neurol. 389, 1-11.

Monte, A.P., Marona-Lewicka, D., Cozzi, N.V., Nichols, D.E. 1993. Synthesis and pharmacological examination of benzofuran, indan, and tetralin analogues of 3,4(methylenedioxy)amphetamine. J. Med. Chem. 36, 3700-3706.

Nagatomo, T., Rashid, M., Muntasir, H.A., Komiyama, T. 2004. Functions of 5-HT2A receptor and its antagonists in the cardiovascular system. Pharmacol. Ther. 104, 59-81.

Nichols, D.E. 2004. Hallucinogens. Pharmacol. Therapeut. 101, 131-181.

Passie, T., Halbern, J.H., Stichtenoth, D.O., Emrich, H.K., Hintzen, A. 2008. The pharmacology of lysergic acid diethylamide: a review. CNS Neurosci. Ther. 14, 295-314.

Paxinos, G., Watson, C. 2005. The rat brain in stereotaxic coordinates 5th Edition. Elsevier Academic Press.

Petitti, D.B., Sidney, S., Quesenberry, C., Bernstein, A. 1998. Stroke and cocaine or amphetamine use. Epidemiol. 9, 596-600.

Pontieri, F.E., Tanda, G., Orzi, F., Di Chiari, G. 1996. Effect of nicotine in the nucleus accumbens and similarity to those of addictive drugs. Nature 382, 225-227.

Rothman, R.B., Baumann, M.H., Savage, J.E., Rauser, L., McBride, A., Hufeisen, S.J., Roth, B.L. 2000. Evidence for possible involvement of 5-HT2B receptors in the cardiac valvulopathy associated with fenfluramine and other serotonergic medications. Circulation 102, 2836-2841.

Rothman, R.B., Baumann, M.H. 2002. Therapeutic and adverse actions of serotonin transporter substrates. Pharmacol. Ther. 95, 73-88. 
Sato, H., Skelin, I., Diksic, M. 2010. Chronic buspirone treatment decreases 5-HT1B receptor densities and the serotonin transporter but increases the density of 5-HT2A receptors in the bulbectomized rat model of depression: an autoradiographic study. Brain Res. 1345, 28-44.

Setola, V., Hufeisen, S.J., Grande-Allen, K.J., Vesely, I., Glennon, R.A., Blough, B., Rothman, R.B., Roth, B.L. 2003. 3,4-Methylenedioxymethamphetamine (MDMA, "Ecstasy") induces fenfluramine-like proliferative actions on human cardiac valvular interstitial cells in vitro. Mol. Pharmacol. 63, 1223-1229.

Stanczuk, A., Morris, N., Gardner, E.A., Kavanagh, P. 2013. Identification of (2aminopropyl)benzofuran (APB) phenyl ring positional isomers in Internet purchased products. Drug Testing Anal. 5, 270-276.

Strazielle, C., Lalonde, R., Amdiss, F., Botez, M.I., Hébert, C., Reader, T.A. 1998.

Distribution of dopamine transporters in basal ganglia of cerebellar ataxic mice by [ $\left.{ }^{125} \mathrm{I}\right] \mathrm{RTI}-$ 121 quantitative autoradiography. Neurochem. Int. 32, 61-68.

Sulzer, D., Sonders, M.S., Poulsen, N.W., Galli, A. 2005. Mechanisms of neurotransmitter release by amphetamines: A review. Prog. Neurobiol. 75, 406-433.

UK Home Office, 04 June 2013. https://www.gov.uk/government/news/nbome-and-benzofuryto-be-banned

Vardakou, I., Pistos, C., Spiliopoulou, C. 2011. Drugs for youth via Internet and the example of mephedrone. Toxicol. Lett. 201, 191-195.

Villaźon, M., Padín, J.F., Cadavid, M.I., Enquix, M.J., Tristán, H., Orallo, F., Loza, M.I. 2002. Characterization of serotonin receptors in rat isolated aorta. Biol. Pharm. Bull., 25, 584-590. 
Willuhn, I., Wanat M.J., Clark, J.J., Phillips, P.E. 2010. Dopamine signaling in the nucleus accumbens of animals self-administering drugs of abuse. Curr. Topics Behav. Neurosci. 3, 2971.

Yorgason, J.T., Espana, R.A., Jones, S.R. 2011. Demon voltammetry and analysis software: analysis of cocaine-induced alterations in dopamine signaling using multiple kinetic measures. J. Neurosci. Meth. 202, 158-164. 
Figure 1. Binding of 5-APB at the dopamine transporter and 5-HT $\mathrm{HA}_{2 \mathrm{~A}}$ receptor sites. A: Representative computer-enhanced images of brain slices incubated with the selective dopamine transporter ligand [ ${ }^{125}$ I]RTI121 and exposed to increasing concentrations of 5-APB. Note the 5-APB concentration-dependent reduction in the radioligand signal intensity in the caudate and accumbens. B: Representative computer-enhanced images of brain slices incubated with the $5-\mathrm{HT}_{2 \mathrm{~A}}$ receptor ligand $\left[{ }^{3} \mathrm{H}\right]$ ketanserin and exposed to increasing concentrations of 5-APB. Note the 5-APB concentration-dependent reduction in the radioligand signal intensity in the prefrontal cortex. C: Pooled data from 6 rats showing the concentration response curves for displacement of $\left[{ }^{125}\right.$ I]RTI121 by 5-APB in both the caudate $(\mathrm{CPu} \bullet)$ and accumbens (NAc $\circ), \mathrm{IC}_{50} \mathrm{~S}$ are 4.1 and $2.2 \times 10^{-5} \mathrm{M}$ respectively. D: Pooled data from 5 rats showing the concentration response curves for displacement of $\left[{ }^{3} \mathrm{H}\right]$ ketanserin by 5 -APB in both the NAc (O) and prefrontal cortex (PFC •), $\mathrm{IC}_{50} \mathrm{~S}$ are 3.9 and $6.5 \times 10^{-6} \mathrm{M}$ respectively. Values and means \pm SEM, $n=5 / 6$.

Figure 2. Left panel: Raw data after application of 5-APB to the accumbens slice and calibrations. (a) typical calibration in $5 \mu \mathrm{M}$ dopamine (DA). (b) typical experiment where dopamine is electrically evoked every 5 min (upward arrows), after 3 baseline stimulations 5APB is added to the superfusate, within $10 \mathrm{~min}$ there is an increase in basal (non-stimulated) dopamine levels. (c) calibration of carbon electrode with $10 \mu \mathrm{M}$ 5-APB. It can be seen that 5APB does not affect our signal, thus the increase in the signal seen in $(b *)$ can be attributed to dopamine. Right panel: 5-APB increases basal levels of dopamine in the accumbens. (d) the input voltage applied to the carbon electrode which goes from 0 to -1 , up to +1.4 , back to 1 and finally back to $0 \mathrm{~V}$ at $480 \mathrm{~V} / \mathrm{s}$. The whole voltage scan takes $20 \mathrm{~ms}$. (e) shows the oxidation and reduction peaks at the carbon electrode after applying $5 \mu \mathrm{M}$ dopamine, data is from the calibration shown in Fig 2 a and taken at the time denoted by * (f) oxidation (at +0.6 $\mathrm{V}$ ) and reduction (at $-0.2 \mathrm{~V}$ ) peaks from dopamine release in the accumbens, after application of $10 \mu \mathrm{M} 5$-APB, as shown in Fig $2 \mathrm{~b}$ and taken at the time denoted by $*$ i.e. at the peak effect. Note that the oxidation peak is at the same place for both exogenous (a) and endogenous (b) dopamine. (g) the lack of effect of 5-APB, when applied to the electrode (from $2 \mathrm{c}^{*}$ ), in the absence of neural tissue. These data show that the peak seen in (b) is from release of dopamine and not oxidation of 5-APB, and that 5-APB does not affect electrode sensitivity. 
Figure 3. Effect of 5-APB on electrically evoked dopamine in the accumbens shell. Left panel shows representative raw data of electrically evoked dopamine efflux in the accumbens shell before application of 5-APB (control) and after $60 \mathrm{~min}$ of 5-APB at $0.1,1$ or $10 \mu \mathrm{M}$. The peak dopamine level evoked, on each of the control stimulation, is about $300 \mathrm{nM}$ dopamine and $20 \mathrm{~s}$ of data is shown for each efflux event. Electrical stimulations are given at the upward arrow. Right panel shows the concentration dependent increase in dopamine efflux (AUC) after application of 5-APB. Values are means $\pm \mathrm{SEM}, \mathrm{n}=3-6 . * \mathrm{P}<0.05$ versus all other groups.

Fig 4. Effect of 5-APB on 5-HT 2 receptors in rat aorta and fundus. A. 5-APB caused contraction of rat aorta, an effect completely blocked by the 5- $\mathrm{HT}_{2 \mathrm{~A}}$ receptor antagonist ketanserin $(0.1 \mu \mathrm{M})$. B. 5-HT, 5-APB and MDMA all caused contraction of rat fundus in a concentration dependent manner with the order of potency being 5-HT > 5-APB > MDMA. C. The effect of 5-APB in the rat fundus was attenuated by the $5-\mathrm{HT}_{2 \mathrm{~B}}$ receptor antagonist RS127445 $(1 \mu \mathrm{M})$. Values are means \pm SEM, $\mathrm{n}=4-6$. 
$\begin{array}{ll}\text { A. }\left[{ }^{125}\right] \text { RTI121 } & \text { B. }\left[{ }^{3} H\right] \text { ketanserin }\end{array}$
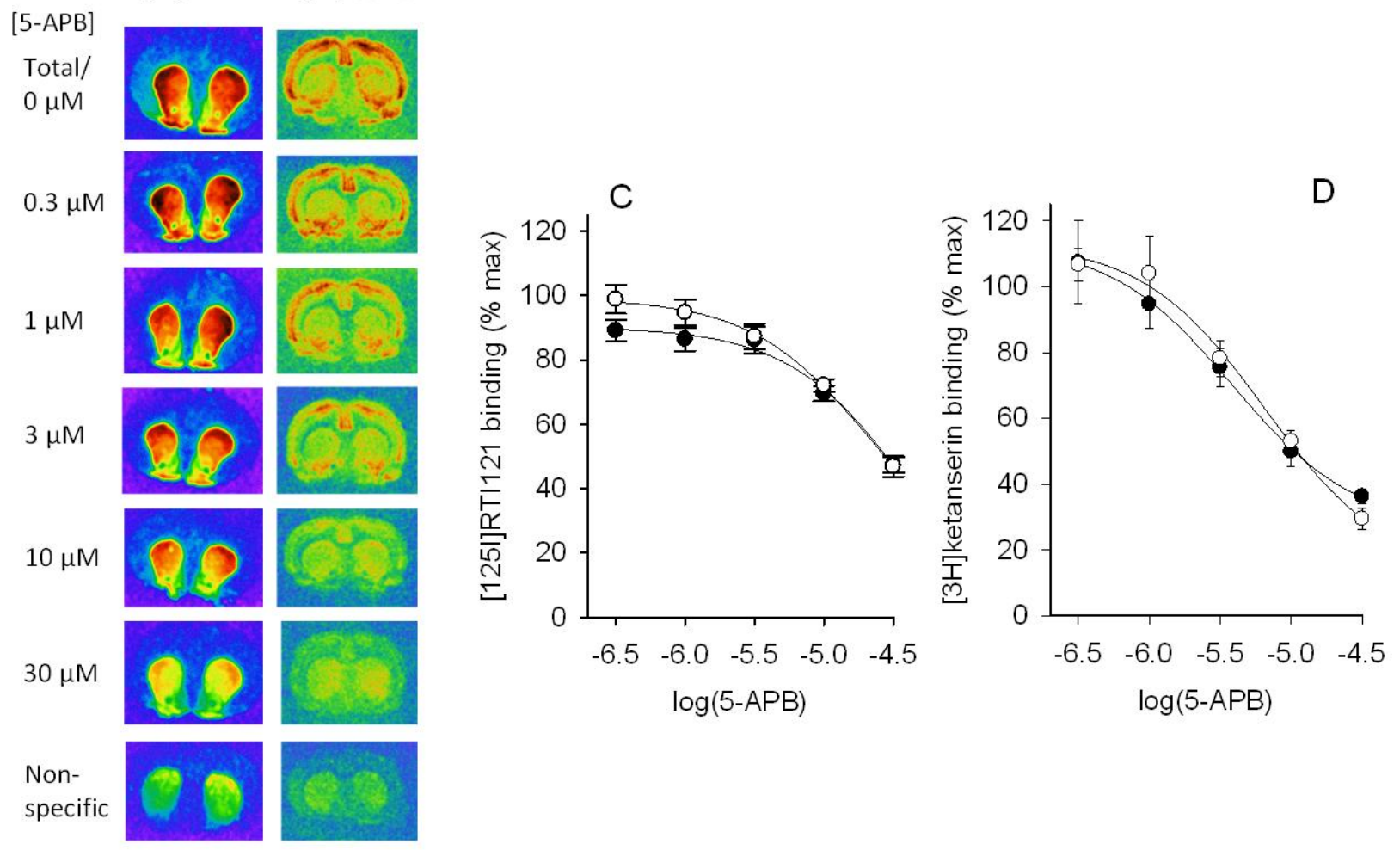

Figure 1 

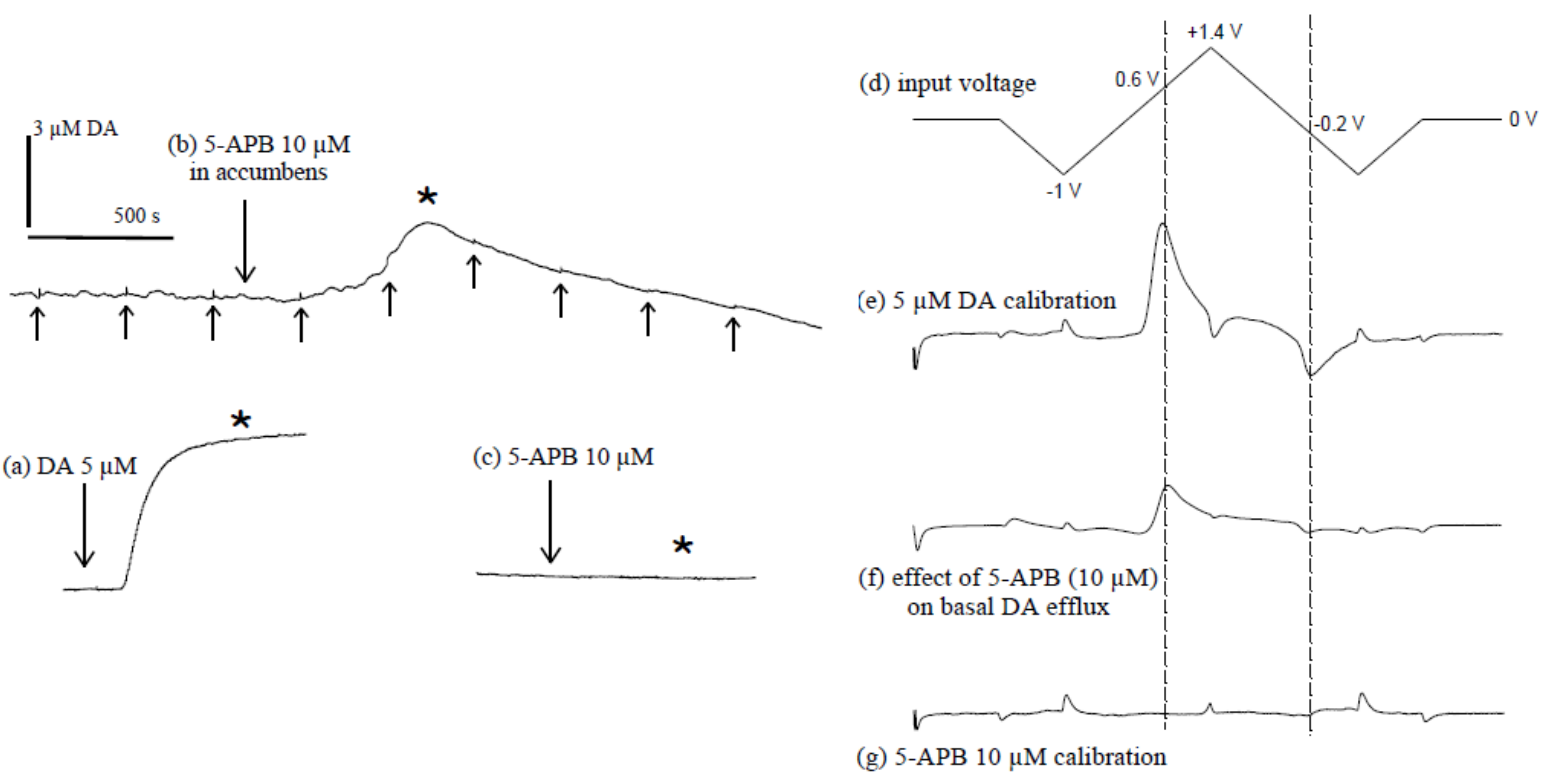

Figure 2 

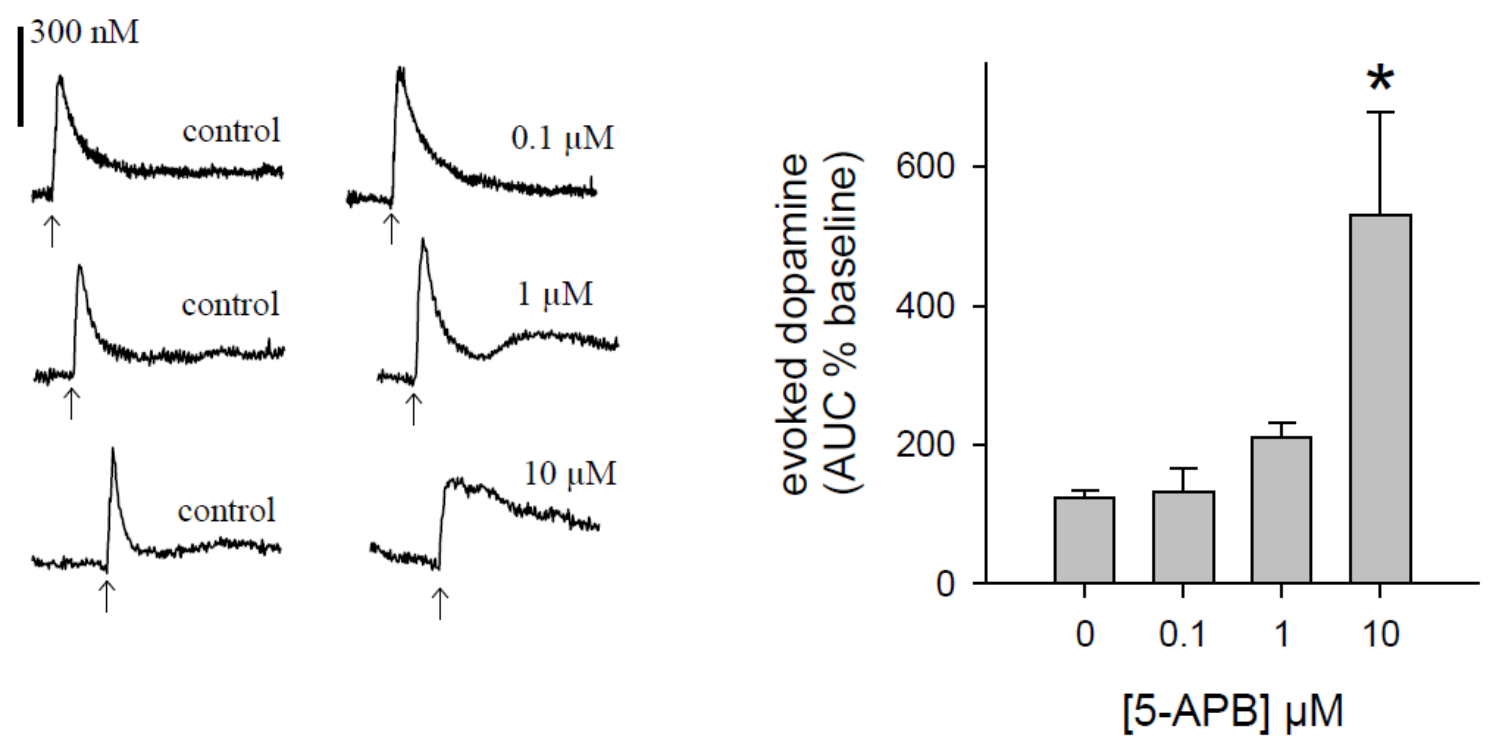

Figure 3 

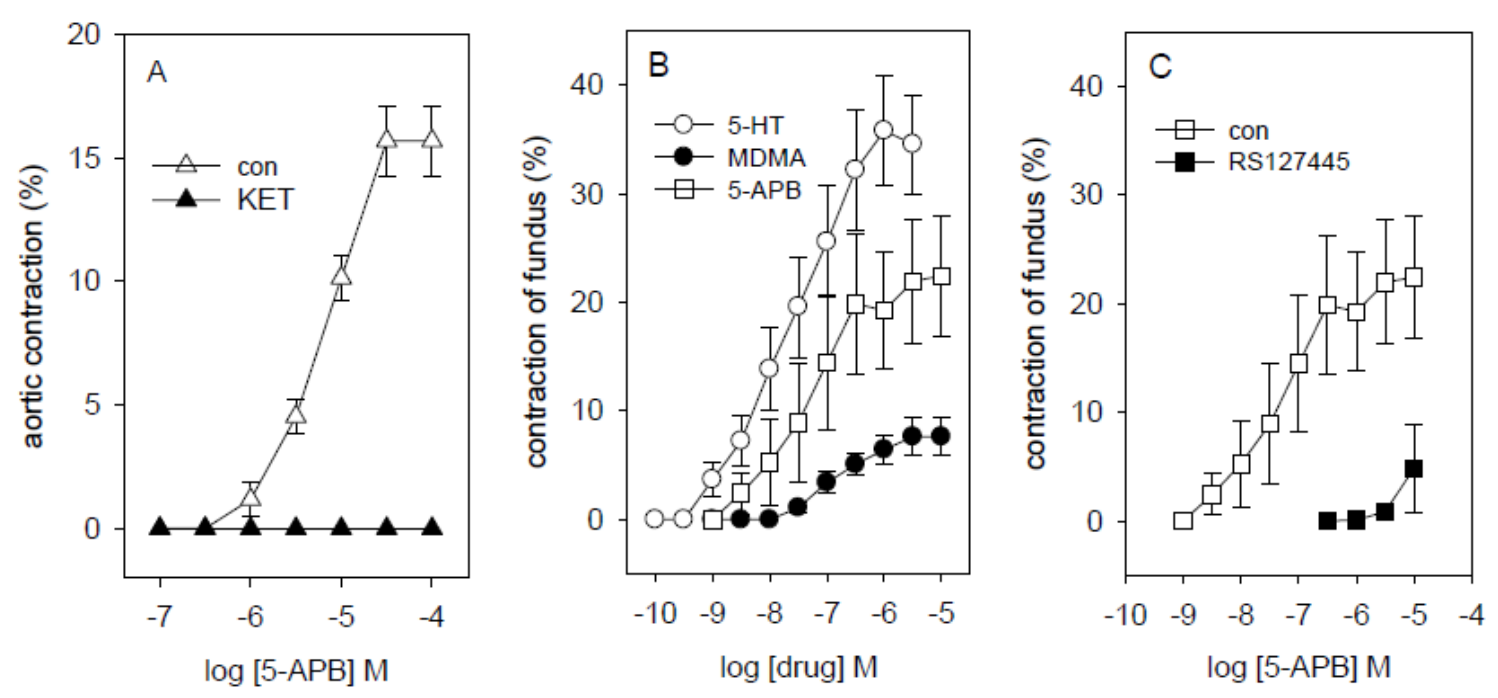

Figure 4 
Highlights

- 5-APB (Benzofury) has been associated with 10 recent drug-related deaths in the UK

- 5-APB displaces radioligands at the dopamine transporter and 5- $\mathrm{HT}_{2 \mathrm{~A}}$ receptor

- Voltammetric assessment of 5-APB on accumbens dopamine suggests amphetaminelike effects

- 5-APB contractions of rat aortic preparations suggest potential hypertensive effects

- 5-APB contractions of rat fundus predict potential valvulopathies. 